\title{
Recycle of Wastewater from Lead-Zinc Sulfide Ore Flotation Process by Ozone/BAC Techonlogy
}

\author{
Liu Xingyu ${ }^{1}$, Chen Bowei ${ }^{1}$, Li Wenjuan ${ }^{1}$, Song Yongsheng ${ }^{1}$, Wen Jiankang ${ }^{1}$, Wang Dianzuo ${ }^{2}$ \\ ${ }^{1}$ National Engineering Laboratory of Biohydrometallurgy, General Research Institute for Nonferrous Metals, Beijing, China; \\ ${ }^{2}$ General Research Institute for Nonferrous Metals, Beijing, China. \\ Email: wellwoodliu@gmail.com
}

Received 2013

\begin{abstract}
Lead-zinc sulphide ore contains lead sulphide (galena), and zinc sulphide (sphalerite). In the first flotation stage, galena is rendered hydrophobic with an organic collector such as xanthate, while sphalerite is kept from floating by depressants, and in the second flotation stage, activator was used to activated zinc flotation. Since the organic regent used are different in the two flotation stage, wastewater from the second zinc flotation stage can't be directly recycled to the first lead flotation stage. Wastewater from flotation process for concentrating lead-zinc sulphide ore often containing organic compounds such as diethyldithiocarbamate(DDTC), xanthate, terpenic oil(2\# oil) and thionocarbamate esters (Z-200), are environmentally hazardous. Their removal from contaminated water and the reuse of the water is one of the main challenges facing lead-zinc sulphide ore processing plants. In this study, synthetic wastewater containing DDTC, xanthate, 2\# oil and Z-200 at concentrations ranging from 21 to $42 \mathrm{mg} / \mathrm{L}$ was fed into an Ozone/Biological activated carbon (BAC) reactor. Analyses of the effluent indicated a chemical oxygen demand (COD) removal over $86.21 \%$ and Total organic carbon (TOC) removal over $90.00 \%$ were achieved under Hydraulic retention time (HRT) of $4 \mathrm{~h}$ and $\mathrm{O}_{3}$ feeding concentration of $33.3 \mathrm{mg} / \mathrm{L}$. The effluent was further recycled to the lab scale lead concentrating process and no significant difference was found in compare with fresh water. Furthermore, lead-zinc sulphide mineral concentrating process was carried out at lab scale. The produced wastewater was treated by Ozone/BAC reactor at $\mathrm{O}_{3}$ feeding concentration of $16.7 \mathrm{mg} / \mathrm{L}$ and HRT of $4 \mathrm{~h}$. The effluent analysis showed that TOC removal was $74.58 \%$. This effluent was recycled to the lab scale lead-zinc sulphide mineral concentrating process and the recovery of lead was not affected. The results showed that by using Ozone/BAC technology, the lead-zinc sulphide mineral processing wastewater could be recycled.
\end{abstract}

Keywords: Lead-Zinc Sulphide Ore; Ozone/BAC; Flotation Wastewater; Recycle

\section{Introduction}

Flotation is in fact the most common process in metallic mineral separation and is the main way for recovering valuable metals as lead $(\mathrm{Pb})$ and zinc (Zn) (Barbaro, 2000). For Lead-zinc sulphide ore, the most widely used method is that of two stage selective flotation, where the zinc and iron minerals are depressed, allowing the galena to float, followed by the activation of the zinc minerals in the lead tailings to allow a zinc float (Wills and NapierMunn, 2005; Kinal et al., 2009). Wastewater from flotation process for concentrating lead-zinc sulphide ore often containing organic compounds such as DDTC, xanthate, 2\# oil and Z-200, are environmentally hazardous. Since the organic regent used are different in the two flotation stage, wastewater from the second zinc flotation stage can't be directly recycled to the first lead flotation stage. Thus such organic regents removal from contaminated water and the reuse of the water is one of the main challenges facing lead-zinc sulphide ore processing plants.

Ozonation of water is a well-known technology and the strong oxidative properties of ozone have been well documented (Glaze et al., 1987). Ozone alone has the ability to generate hydroxyl radicals $(\bullet \mathrm{OH})$ when applied to wastewater due to side reactions with electron-rich moieties, such as amines, phenols, and alkoxylated aromatics (Nöthe et al., 2009; Pocostales et al. 2010). In this way, the aromatic or hydrophobic organic compounds can be converted to more hydrophilic, biodegradable organic compounds, such as aldehydes, carboxylic acids, ketones and other organic acids (Huang et al., 2005; Hammes et al., 2006). With respect to oxidation byproducts, recent studies suggest that post-ozone biological filtration (BAC) is sufficient to eliminate the toxicity that has been attributed to ozonation of effluent organic matter (EfOM) (Chiang et al., 2002; Xu et al., 2007; Stalter et al., 2010). Since Oone/BAC technology has many advantages such as low cost, high efficiency, short HRT, it might be 
a suitable treatment for wastewater effluent from leadzinc sulphide ore flotation.

The purpose of this study was to determine whether ozone/BAC technology could be applied in lead-zinc sulphide ore flotation wastewater treatment. That include investigate the characteristics of degradation/conversion of organic regents used in lead-zinc flotation process in ozone/BAC process and whether the treated water could be reused back to lead circuit. The following sections summarize the methodology and results from synthetic flotation wastewater and real lab produced flotation wastewater treatment over the course of five months of continuous operation and the evaluation of recycle of the treated water.

\section{Materials and Methods}

\subsection{Synthetic Wastewater and Real Lab Produced Wastewater}

Synthetic wastewater and real lab produced wastewater were fed into ozonation and BAC treatment system, respectively. Synthetic wastewater composed of DDTC, xanthate, 2\# oil and Z-200, with concentration adjusted to concentrations ranging from 21 to $42 \mathrm{mg} / \mathrm{L}$. The above regents were provided by Chehe lead-zinc mining Crop. (Guanxi, China). The lead-zinc sulphide ore used in this research were provided by Zhangbeizhuan lead-zinc mine
(Heibei, China). Table 1 were the chemical composition of the two Zhangbeizhuan lead-zinc sulphide ore samples used in this research. The lab produced wastewater was from lab scale Zhangbeizhuan lead-zinc sulphide ore flotation process via a flow sheet showed in Figure 1.

Table 1. Chemical composition of the two Zhanbeizhuan leadzinc sulphide ore samples used in this research.

\begin{tabular}{ccc}
\hline \multirow{2}{*}{ Elements } & \multicolumn{2}{c}{ Composition (\%) } \\
\cline { 2 - 3 } & Sample A & Sample B \\
$\mathrm{Cu}$ & - & 0.071 \\
$\mathrm{~Pb}$ & 3.47 & 2.86 \\
$\mathrm{Zn}$ & 1.87 & 2.01 \\
$\mathrm{Fe}$ & - & 9.41 \\
$\mathrm{Cd}$ & - & 0.014 \\
$\mathrm{Ca}$ & - & 0.29 \\
$\mathrm{Mg}$ & - & 0.46 \\
$\mathrm{As}$ & - & 1.87 \\
$\mathrm{Al} \mathrm{O}_{3}$ & - & 10.03 \\
$\mathrm{SiO} \mathrm{O}_{2}$ & - & 57.88 \\
$\mathrm{Ag} / \mathrm{g} / \mathrm{t}$ & - & 93.5 \\
$\mathrm{Au} / \mathrm{g} / \mathrm{t}$ & - & 0.4 \\
$\mathrm{Mo}$ & - & 0.001 \\
$\mathrm{C}$ & - & 0.98 \\
\hline
\end{tabular}

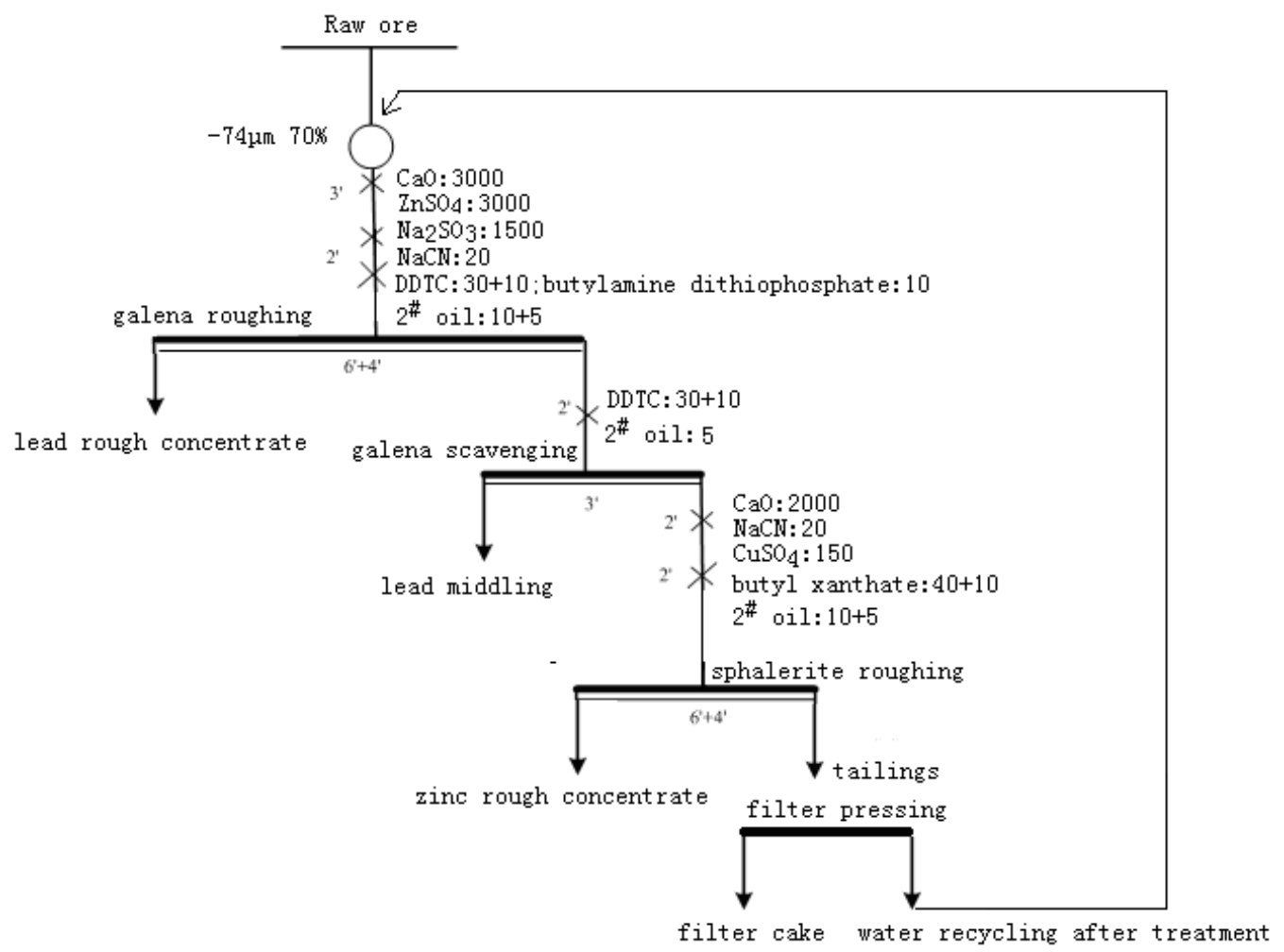

Figure 1. Flow sheet of the Zhangbeizhuan lead-zinc sulphide ore flotation process (time used were minute, concentration showed were mg/l). 


\subsection{Reactor Set-Up and Reuse of the Treated Wastewater}

Ozone was generated from oxygen by means of a PLASMA ozone generator with maximum capacity of $20 \mathrm{mg} / \mathrm{min}$. The ozone reaction chamber is a $10 \times 20 \times 20(\mathrm{~cm})$ rectangular plexiglas tank and had working volume of $2 \mathrm{~L}$. There was a cover on the top of the tank that prevented the volatilization of ozone. The tank was fitted at the bottom with a stone diffuser connected to the ozone generator. Because of this configuration, ozone concentration in the gas phase could not be independently adjusted and the dose of ozone was controlled by changing the gas flow rate. Effluent was drawn from a port at $10 \mathrm{~cm}$ above the base and entered another similar plexiglas tank filled with activated carbon for BAC treatment. During the start-up stage, activated sludge were inoculated in to the BAC reactor which would allow the growth of bacteria on the surface of the activated carbon.

During the whole experiments, the HRT of ozone reactor and BAC reactor were maintained at $2 \mathrm{~h}, 2 \mathrm{~h}$ respecttively. The reuse of the treated water to the lead flotation circuit was conducted via a flow sheet showed in Figure 2.

\subsection{Analytical Methods}

TOC was measured with a TOC analyzer (SHIMADZU, TOC-5000). COD were determined by the standard photo- metric method (DWAF, 1992) using the Spectroquant Nova 60 Photometer supplied by Merck NT PTY Ltd. Samples for COD analyses were digested with Merck Thermo reactor Model TR 300 and then analysed by the Merck Nova 60 photometer.

\section{Results and Discussion}

\subsection{Ozone/BAC Reactor Performance Treating Synthetic Wastewater}

Synthetic wastewater composed of DDTC, xanthate, 2\# oil and Z-200, with concentration adjusted to $42 \mathrm{mg} / \mathrm{l}, 28$ $\mathrm{mg} / \mathrm{l}, 21 \mathrm{mg} / \mathrm{l}$ and $21 \mathrm{mg} / \mathrm{l}$ respectively was feeding into the ozone/BAC reactor. As mentioned before, the HRT was maintained at $4 \mathrm{~h}$. Different ozone feeding concentration was applied to the ozone reactor. Under each feeding concentration, the reactor was operated for one week, and then the influent and effluent were sampled for TOC and COD analysis. Table 2 showed TOC and COD removal of the Ozone/BAC reactor treating synthetic wastewater under different feeding ozone concentration. Ozone feeding concentration could significantly affect the TOC and COD removal, at relative low feeding concentration of $13.2 \mathrm{mg} / \mathrm{L}$, the TOC removal were only $58.33 \%$ while at ozone feeding concentration of $33.3 \mathrm{mg} / \mathrm{L}$, the TOC removal exceeded $90 \%$. There is very strong correlation of TOC and COD concentration according to the four organic regents which added into the synthetic wastewater (Table 2).

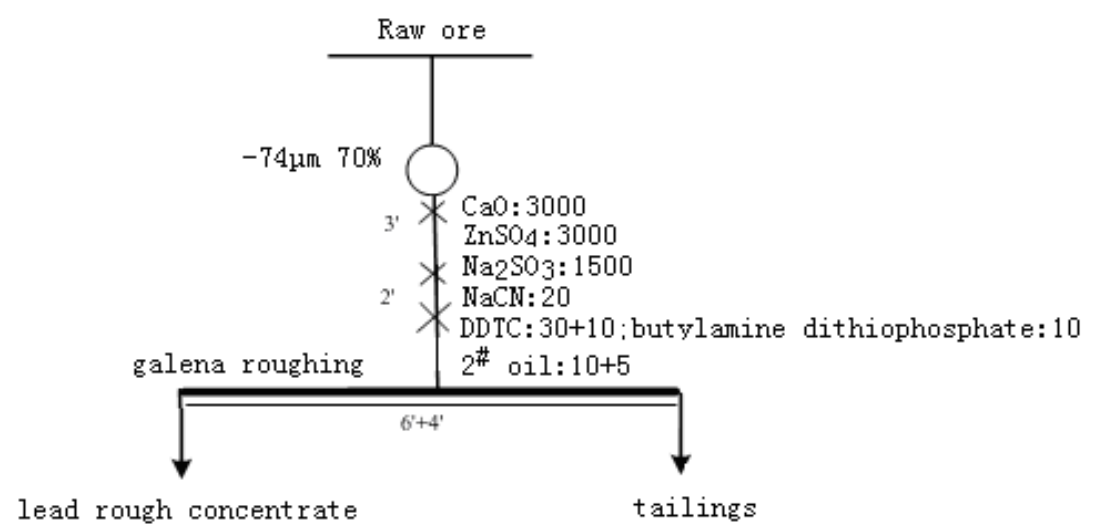

Figure 2. Flow sheet of the lead flotation circuit which use the treated wastewater, untreated wastewater and fresh water.

Table 2. TOC and COD removal of the Ozone/BAC reactor treating synthetic wastewater.

\begin{tabular}{|c|c|c|c|c|c|c|}
\hline $\begin{array}{l}\text { Ozone concentration } \\
(\mathrm{mg} / \mathrm{L})\end{array}$ & $\begin{array}{c}\text { Influent TOC } \\
\text { (mg/L) }\end{array}$ & $\begin{array}{c}\text { Effluent TOC } \\
(\mathrm{mg} / \mathrm{L})\end{array}$ & $\begin{array}{c}\text { TOC removal } \\
(\%)\end{array}$ & $\begin{array}{c}\text { Influent COD } \\
(\mathrm{mg} / \mathrm{L})\end{array}$ & $\begin{array}{c}\text { Effluent COD } \\
\text { (mg/L) }\end{array}$ & $\begin{array}{c}\text { COD removal } \\
(\%)\end{array}$ \\
\hline 13.3 & 18 & 7.5 & 58.33 & 85 & 42 & 50.59 \\
\hline 16.7 & 18 & 5.4 & 70 & 87 & 50 & 42.53 \\
\hline 22.2 & 18 & 1.8 & 90 & 116 & 16 & 86.21 \\
\hline 33.3 & 18 & 1.8 & 90 & 98 & 12 & 87.76 \\
\hline 66.6 & 18 & - & - & 82 & 22 & 73.17 \\
\hline
\end{tabular}




\subsection{Reuse of the Treated Synthetic Wastewater to the Lead Circuit}

Under the ozone feeding concentration of $33.3 \mathrm{mg} / \mathrm{L}, 10 \mathrm{~L}$ effluent was collected and recycled to the lead circuit. Zhangbeizhuang ore sample A was used for this part of work. Table 3 showed the comparison of lead recovery in the lead circuit using treated synthetic wastewater and fresh water. Compared with fresh water, by using the treated synthetic wastewater, the production rate was increased from $10.31 \%$ to $11.81 \%$ while the lead grade in the lead concentrate was decreased from $29.92 \%$ to $26.30 \%$, thus the lead recovery has no significant change(treated synthetic wastewater: $88.95 \%$, fresh water: 88.89\%). By using the treated synthetic wastewater, zinc grade have no significant change but the zinc recovery increased from 15.5 to $18.61 \%$, which indicate that using treated synthetic wastewater, small amount of zinc may entering lead circuit. This effect is now under further investigation.

\subsection{Ozone/BAC Reactor Performance Treating Real Lab Produced Wastewater}

Lab scale Zhangbeizhuang ore sample B flotation was carried out for the production of real lab flotation wastewater. Table 4 showed TOC removal of the Ozone/BAC reactor treating real lab produced flotation wastewater under different ozone feeding concentration. Unlike synthetic wastewater, there is no strong correlation between ozone feeding concentration and the TOC removal. Under feeding ozone concentration of $16.7 \mathrm{mg} / \mathrm{l}$, the highest TOC removal of $74.58 \%$ was achieved. It is worth to note that TOC of the lab produced wastewater is lower than the synthetic wastewater. The removal rate for the produced wastewater is lower than synthetic wastewater, this may due to more complex organic within the produced wastewater.

\subsection{Reuse of the Treated Real Flotation Wastewater to the Lead Circuit}

Under the ozone feeding concentration of $16.7 \mathrm{mg} / \mathrm{L}, 10$ $\mathrm{L}$ treated lab produced wastewater effluent was collected. Together with another $10 \mathrm{~L}$ untreated lab produced wastewater and fresh water were applied to the lead flotation process respectively. Zhangbeizhuang ore sample B was used for this part of work. Table 5 showed the compareson of lead recovery in the lead circuit using treated real lab produced wastewater, untreated real lab produced wastewater and fresh water. Compared with fresh water, by using the untreated lab produced wastewater, the production rate was increased from $10.10 \%$ to $15.35 \%$, the lead recovery increased from $83.40 \%$ to $87.83 \%$, and the lead grade in the lead concentrate was significantly decreased from $23.57 \%$ to $16.71 \%$. Meanwhile, the zinc grade in the lead concentrate increased from $2.62 \%$ to $8.84 \%$ and the zinc recovery in the lead concentrate increased from $12.05 \%$ to $65.34 \%$. The above results indicated that directly recycle of zinc flotation wastewater to the lead circuit may have negative effect on lead flotation, large amount of zinc will entering lead circuit. When the treated lab produced wastewater was used, all the indices were nearly similar if compared with fresh water (Table 5). This indicated that by using ozone/BAC technology, the treated flotation wastewater could recycle to lead circuit, and the lead flotation was not affected.

\section{Conclusions}

This study investigates the performance of ozone/BAC treatment processes for synthetic lead-zinc flotation wastewater and real lab produced lead-zinc flotation wastewater, and evaluates the reuse of treated water back to lead circuit. The conclusions obtained from this study are as follows:

Table 3. Comparison of lead recovery in the lead circuit using treated synthetic wastewater and fresh water.

\begin{tabular}{|c|c|c|c|c|c|c|c|c|c|c|}
\hline & \multicolumn{2}{|c|}{ Production rate $(\%)$} & \multicolumn{2}{|c|}{ Lead grade(\%) } & \multicolumn{2}{|c|}{ Zinc grade (\%) } & \multicolumn{2}{|c|}{ Lead recovery(\%) } & \multicolumn{2}{|c|}{ Zinc recovery(\%) } \\
\hline & A* & B* & A* & B* & A* & B* & A* & $\mathbf{B}^{*}$ & A* & B* \\
\hline Lead concentrate & 11.87 & 10.31 & 26.3 & 29.92 & 2.87 & 2.84 & 89 & 88.89 & 18.6 & 15.5 \\
\hline Tailing & 88.13 & 89.69 & 0.44 & 0.43 & 1.69 & 1.78 & 11.1 & 11.11 & 81.4 & 84.5 \\
\hline Raw ore & 100 & 100 & 3.51 & 3.47 & 1.83 & 1.9 & 100 & 100 & 100 & 100 \\
\hline
\end{tabular}

*A: treated synthetic wastewater; ${ }^{*} \mathrm{~B}$ : fresh water.

Table 4. TOC removal of the Ozone/BAC reactor treating real lab produced flotation wastewater.

\begin{tabular}{cccc}
\hline Ozone concentration (mg/l) & Influent TOC (mg/l) & Effluent TOC (mg/l) & TOC removal (\%) \\
\hline 13.3 & 14.4 & 5.06 & 3.66 \\
16.7 & 14.4 & 4.04 \\
22.2 & 14.4 & 74.58 \\
33.3 & 14.4 & 5.31 & 63.13 \\
66.6 & 14.4 & 6.49 \\
\hline
\end{tabular}


Table 5. Comparison of lead recovery in the lead circuit using treated lab produced wastewater, untreated lab produced wastewater and fresh water.

\begin{tabular}{lcccccccccc}
\hline & \multicolumn{3}{c}{ Raw ore } & \multicolumn{3}{c}{ Lead concentrate } & \multicolumn{3}{c}{ Tailing } \\
\cline { 2 - 10 } & A* & B* & C* & A* & B* & C* & A* & B* & C* \\
\hline Production rate (\%) & 100 & 100 & 100 & 9.66 & 15.35 & 10.1 & 90.34 & 84.65 & 89.9 \\
Lead grade (\%) & 2.75 & 2.92 & 2.85 & 23.69 & 16.71 & 23.57 & 0.51 & 0.42 & 0.53 \\
Zinc grade (\%) & 1.98 & 2.08 & 1.99 & 2.73 & 8.84 & 2.62 & 1.9 & 0.85 & 1.92 \\
Lead recovery (\%) & 100 & 100 & 100 & 82.4 & 87.83 & 83.4 & 17.6 & 12.17 & 16.6 \\
Zinc recovery (\%) & 100 & 100 & 100 & 12.9 & 65.34 & 12.05 & 87.09 & 34.66 & 87.95 \\
\hline
\end{tabular}

*A: treated lab produced wastewater; ${ }^{*} \mathrm{~B}$ : untreated lab produced wastewater; ${ }^{*} \mathrm{C}$ : fresh water.

a) By using ozone/BAC reactor, under HRT of $4 \mathrm{~h}$ and $\mathrm{O}_{3}$ feeding concentration of $33.3 \mathrm{mg} / \mathrm{L}$, synthetic wastewater composed of DDTC, xanthate, 2\# oil and Z-200 could be effectively treated, the COD removal over $86.21 \%$ and TOC removal over $90.00 \%$. The reuse of synthetic wastewater to lead circuit has no significant difference in compare with fresh water.

b) Directly reuse of lab produced flotation wastewater to the lead circuit has negative effect on lead flotation. By using ozone/BAC reactor, under HRT of $4 \mathrm{~h}$ and feeding ozone concentration of $16.7 \mathrm{mg} / \mathrm{l}$, the highest TOC removal of $74.58 \%$ was achieved when treating lab produced flotation wastewater. The treated wastewater could recycle to lead circuit, and the lead flotation was not affected.

c) The above results showed that by using Ozone/BAC technology, the lead-zinc sulphide mineral processing wastewater could be recycled.

\section{Acknowledgements}

This work was financially supported by National Science and technology support program of China (2009BAB45B01).

\section{REFERENCES}

[1] Barbaro, M., 2000. Encyclopedia of Separation Science. Editor-in-Chief: Ian, D.W. (ed), pp. 3215-3218, Academic Press, Oxford.

[2] Wills, B.A. and Napier-Munn, T., 2005. Wills' Mineral Processing Technology (Seventh Edition), pp. 267-352, Butterworth-Heinemann, Oxford.

[3] Kinal, J., Greet, C. and Goode, I., 2009. Effect of grinding media on zinc depression in a lead cleaner circuit. Minerals Engineering 22(9-10), 759-765.
[4] Glaze, W.H., Kang, J.-W. and Chapin, D.H., 1987. The Chemistry of Water Treatment Processes Involving Ozone, Hydrogen Peroxide and Ultraviolet Radiation. Ozone: Science \& Engineering 9(4), 335-352.

[5] Nöthe, T., Fahlenkamp, H. and Sonntag, C.v., 2009. Ozonation of Wastewater: Rate of Ozone Consumption and Hydroxyl Radical Yield. Environmental Science \& Technology 43(15), 5990-5995.

[6] Pocostales, J.P., Sein, M.M., Knolle, W., von Sonntag, C. and Schmidt, T.C., 2010. Degradation of Ozone-Refractory Organic Phosphates in Wastewater by Ozone and Ozone/Hydrogen Peroxide (Peroxone): The Role of Ozone Consumption by Dissolved Organic Matter. Environmental Science \& Technology 44(21), 8248-8253.

[7] Huang, W.-J., Fang, G.-C. and Wang, C.-C., 2005. The determination and fate of disinfection by-products from ozonation of polluted raw water. Science of The Total Environment 345(1-3), 261-272.

[8] Hammes, F., Salhi, E., Köster, O., Kaiser, H.-P., Egli, T. and von Gunten, U., 2006. Mechanistic and kinetic evaluation of organic disinfection by-product and assimilable organic carbon (AOC) formation during the ozonation of drinking water. Water Research 40(12), 2275-2286.

[9] Chiang, P.C., Chang, E.E. and Liang, C.H., 2002. NOM characteristics and treatabilities of ozonation processes. Chemosphere 46(6), 929-936.

[10] Xu, B., Gao, N.-Y., Sun, X.-F., Xia, S.-J., Simonnot, M.-O., Causserand, C., Rui, M. and Wu, H.-H., 2007. Characteristics of organic material in Huangpu River and treatability with the O3-BAC process. Separation and Purification Technology 57(2), 348-355.

[11] Stalter, D., Magdeburg, A. and Oehlmann, J., 2010. Comparative toxicity assessment of ozone and activated carbon treated sewage effluents using an in vivo test battery. Water Research 44(8), 2610-2620.

[12] DWAF, 1992. Analytical Methods Manual,, Department of Water Affairs \& Forestry, Pretoria 